\title{
The Structure of Bargaining under the Employment Contracts Act
}

\author{
Ian McAndrew*
}

Under the Employment Contracts Act 1991, the structure of contracting is left for negotiation between the parties, rhetorically so that the parties can fashion mutually satisfactory arrangements attuned to their particular needs and circumstances. This paper presents survey data that demonstrates that, while the extent of employee concessions differs between individual and collective contracts, patterns of contract structures are developing by workforce size and pre-Act union strength and show no relationship to the market circumstances or cost pressures under which firms operate.

"Decisions on bargaining structure are at the heart of the management of industrial relations" (Kinnie, 1987:463). The purpose of this paper is to report, through the presentation of research data, on the structure of bargaining, and associated contract structures, emerging under New Zealand's Employment Contracts Act of 1991.

\section{Introduction}

The New Zealand Employment Contracts Act 1991 has attracted considerable attention overseas because it represents such a significant departure from established approaches to labour market regulation in democratic industrialised societies. Fundamental to that departure is the denial of the premise that historically has underlaid and given rationale to industrial regulation: the presumed inequality of bargaining power between the individual employee and the employing organisation.

Historically, Western governments have sought to regulate the labour market in one of two ways, or often in some variation of one or some combination of the two. The approaches have had in common the objective of addressing the presumed inequality of bargaining power in the employment relationship.

In the first approach, legislated procedures have been directed at neutralising the exercise of superior bargaining power, whether by employers or by combinations of employees, by taking the setting of terms and conditions of employment out of the hands of the immediate employer and employee parties. This approach is most obviously embodied in a centralised compulsory arbitration system, such as has operated in Australia, but it does not have to be. It can be compulsory or voluntary, centralised or decentralised, certain or contingent, definitive or parametrical, temporary or permanent.

Department of Management, University of Otago. This research was funded by a grant from the Otago University Research Committee. The author is grateful to Valerie Thompson for research assistance, to Alan Geare for helpful comments, and to Bronwyn Boon for both.

Details of statistical procedures and results are available from the author. 
The second approach has been directed not at neutralising the bargaining power of the parties, but rather at equalising it. Equality of bargaining power in the employment relationship has been legislatively promoted essentially by authorising employees to act collectively, at their option, in dealing with their employer and by requiring that the employer deal with employees collectively if the employees so choose. Again there can be variations, but the North American collective bargaining system can be seen as epitomising this approach.

While the Australian system incorporates bargaining and the North American model incorporates some elements of neutral determination, the "European model", as represented for example by the Austrian social partnership system, might be seen as an illustration of the more complete integration of the two approaches.

To reiterate, what unites these diverse approaches are the underlying presumption that the individual employee is not on equal footing with the employer when it comes to determining terms and conditions of employment and, pursuant to that presumption, the attempt to legislatively address that presumed inequality.

What further unites the two approaches is that they both flow from a "pluralist" frame of reference as distinct from a "unitarist" frame of reference. They assume, that is to say, that while employers and employees have a common interest in the survival and prosperity of both the employing organisation and their relationship, they seek different things out of that relationship, and those differences will, to an extent, lead to conflict between them. Elements of cooperation and conflict co-exist in the employment relationship. From the pluralist perspective, this conflict is seen as natural and inevitable, and its resolution is central to industrial relations (see generally Geare, 1988:20-22).

By contrast, the unitarist frame of reference casts conflict between employers and employees as an indication of something gone wrong: incompatible personalities, poor communications, incomprehension of the inherent community of interest between the parties, or the work of outside agitators (see generally Geare, 1988: 18-20).

\section{The Employment Contracts Act 1991}

How does the Employment Contracts Act relate to the two approaches incorporated within the pluralist philosophy? The most strident supporters of the Act would retreat behind the contention that the question is irrelevant because the pluralist analysis above is simply out of date. And, indeed, much of the rhetoric surrounding the introduction of the Act was unitarist in tone, asserting as it did that if outside union influence could simply be removed from the relationship between employers and employees, the immediate parties would recognise the essential identity of their interests and move forward together unmolested. In such a relationship, bargaining over diverse interests is a non-event.

But rhetoric is for romancing the masses and political power is for pragmatic application. The Employment Contracts Act was a piece of legislation masked in unitarist rhetoric, but it is decidedly not a piece of legislation built on a unitarist philosophy. It is a bargaining law and, as such, it is inherently pluralist. Where it departs from the bargaining model described above is in its denial of an inequality of bargaining power between the individual employee or prospective employee and the employing organisation. Acknowledging no imbalance, the Act makes no effort to redress it. Accordingly, it gives 
priority to individual bargaining and, while allowing for collective bargaining, does nothing to promote it and works to undermine it.

The Act has as a primary stated objective the promotion of "individual freedom". \& Much of the rhetoric surrounding the introduction and implementation of the Act was about freedom, implying in a faintly ridiculous way that those who opposed the Act were against freedom. From a pluralist perspective, this is simply cynical.

To promote unfettered individual freedom in an employment relations context is nothing more than to promote the freedom of the relatively strong individual or organisation to force home an advantage over the relatively weaker party without fear of government intervention. In promoting individual freedoms that far transcend those granted in other representative forums, and that most employees are not in a position to use to advantage, the Act undermines the ability of employees to effectively act collectively when they feel the need to do so.

\section{Employment contract structures}

The distinction between individual and collective bargaining and contracting is reflected in bargaining structures and associated employment contract structures, though there is also more to structures than just that distinction.

The Employment Contracts Act, at Section 18, provides as follows:

Negotiations for an employment contract may, subject to this Act, include negotiations on any matter, including all or any of the following matters:

(a) The question of whether employment contracts are to be individual or collective;

(b) The number and mix of employment contracts to be entered into by any employer.

These two points define the internal dimension of contract "structure". The external dimension is defined by whether contracts are multi-employer or single-employer documents. Determining contract structures might logically be seen as an early and strategically pivotal step for employers and employees in the process of developing new employment contracts.

While there was some diversification of bargaining structures under the Labour Government's 1984 through 1990 labour market reforms, it nonetheless remained true in 1991 that most union-represented employees in New Zealand were covered by national multi-employer awards (Harbridge \& McCaw, 1991). Most were occupational in one sense or the other. While there were relatively few awards that were narrowly occupational across industries, most awards were occupational in that, while confined to a single industry, they did not cover all employees within the industry. As a consequence, even quite small firms were likely to have employees covered by three or four or more awards.

Structurally, the point of the Employment Contracts Act was to replace this predominant pattern of national, occupational multi-employer awards with preferably individual or, if unavoidable, collective arrangements centred at the enterprise or subenterprise levels, or perhaps extending to a parent company or group where applicable. The bias against multi-company documents is incontrovertible, backed as it is by a ban on strikes in pursuit of multi-employer contracts. 
The bias against collective contracts in general is less blatant, but is readily apparent from a brief comparison with the relevant legislative provisions of the North American collective bargaining system.

Boxall $(1990,1991)$ has properly pointed out that New Zealand labour market reforms of the past decade have, in some respects, moved the New Zealand industrial relations system in the direction of the North American model as practiced in the United States. In terms of structural bias on the individual versus collective dichotomy, however, the system intended by the Employment Contracts Act is quite unlike that sponsored by the National Labor Relations Act (NLRA) in the United States.

The NLRA provides for collective bargaining on a voluntary basis at the option of employees. A group of employees seeking to deal collectively with their employer are essentially entitled to do so, at their option, under law. They are quite likely to face a number of legal, technical, tactical and practical obstacles along the road to collective bargaining and, on occasion, the effort to bargain collectively will fail because of these. They are quite likely, too, to end up in a grouping or "bargaining unit" that, as a result of employer input, is different than the grouping originally intended. Nonetheless, there is a presumption in the NLRA that an "appropriate" group of employees bound together by a "commonality of interest", as both terms are defined pursuant to the NLRA, is entitled to bargain collectively at the option of the group.

Procedurally, the keys are the concept of a bargaining unit defining the structure of collective bargaining and resultant contracts, the neutral determination of what bargaining unit is appropriate in response to employee initiative and taking into account the views of the employer, the neutral verification of individual employee authorisation and collective employee election of a bargaining agent, the neutral certification of a bargaining agent for an indefinite period subject only decertification by the group of employees, the guarantee of a secret ballot on both the decision to be represented collectively and the choice of agent, defined limits on employer interference in the employees' exercise of their right to choose, and the requirement that an employer negotiate with, and only with, the duly certified agent elected by the bargaining unit of employees. And underpinning these procedural provisions are the principle of majority rule within appropriate units of employees and the attachment of rights to collectives, at the partial expense of unfettered individual rights, once the unit of employees has elected to act collectively.

There is no pretence that this process in the United States is completely sanitised of all bargaining power considerations. Clearly it is not. Nonetheless, the legislative framework carries the bias, based on the presumed inequality of bargaining power, that a group of employees who feel the need to deal collectively with their employer are entitled to do so.

The provisions of the Employment Contracts Act are in stark contrast in both principle and procedure. The right to bargain collectively is not presumed and is available only by agreement of the employer. The structure of the collective "bargaining unit", if there is to be one, is negotiable. Bargaining agent status is fluid and revokable essentially at will. The verification of the authority of the employee's bargaining agent is in the hands of the employer. The decision to negotiate with the employee's agent lies with the employer, and is revokable. The employer is free to bypass an employee collective and deal individually, either from the outset, or subsequently if dealing with a collective proves difficult. And underpinning it all, even in collective bargaining settings, rights attach to individuals, not to collectives. 
The implications of this procedural vacuum are that the structures of bargaining and contracting -- whether bargaining is to be individual or collective and, where collective, the shape of the covered collective -- are determinable largely in accord with the relative bargaining powers of the employer and employee parties. But, of course, employees who individually lack sufficient bargaining power to negotiate effectively on the substance of their employment conditions, and who accordingly would be most inclined to want to bargain collectively, are no better placed to negotiate themselves into collective arrangements than they are to negotiate effectively on substantive matters.

\section{Projected structural patterns}

So what patterns of emerging bargaining and contract structures are projected by this essentially pluralist analysis? In the simplest terms, the analysis would predict collective contracts for employees with bargaining power and individual contracts for those without. More realistically in just the first year or so under the new framework, the analysis would predict collective contracts for employees already well organised in effective unions at the time of the implementation of the Employment Contracts Act, and individual contracts for the rest of the workforce.

An alternative set of projections might flow from the rhetorical rationale of the Act: bargaining and contract structures, as with substantive terms and conditions of employment, will be found to have been tailored to the needs of the immediate parties, most especially to their need to respond to the demands of the particular markets in which they operate.

Of course, both the elements of contract or bargaining structure, and the range of circumstances that would qualify these absolute projections, are more complex than either projection suggests. Walsh (1991) recognised many of these complexities in presenting a more elaborate set of projections than will be attempted here. The later discussion will make mention of some of these. Clearly however, and for a variety of reasons, many managements have no interest in pressing their advantage over unorganised employees to the point where employees seek to bargain collectively.

The discussion turns next to a brief description of the research project from which the data reported in the balance of the paper are drawn, followed by an indication of the practical significance of contract structures, and a survey of the structural landscape revealed by the research.

\section{The research project}

The research project was designed to monitor and document how New Zealand employers are fashioning new contractual arrangements with their employees, and perhaps employee representatives, during the initial year or so under the Employment Contracts Act. The research began in May, 1991 with a pilot study of 24 South Island firms across a range of industries and workforce sizes, using a multiple case study approach.

The second phase of the research consisted of a mid-1992 postal survey of a random sample of approximately 1800 employing units across all industrial classifications, workforce 


\section{4}

Ian McAndrew

sizes and geographical areas of New Zealand ${ }^{1}$. A total of 557 complete or substantially complete useable responses form the basis of the data for this paper. Where precise percentages are used in the presentation, they are rounded to the nearest whole number. The sample includes some state and local government enterprises, but does not include public service departments. A follow-up interview phase of the project was initiated in October, 1992.

\section{A profile of the respondents}

Most of the immediate respondents to the survey (about 70\%) were the chief executives of their organisations. About $10 \%$ were local branch or area managers of employing units within larger organisations. Only about $8 \%$ were personnel or industrial relations managers. Most of the remainder were other senior managers.

Of the organisations they represented, $39 \%$ were affiliated, as subsidiaries, franchises or branches, with a parent company or group, while $61 \%$ were independent organisations. For the most part, organisations affiliated with a larger group reported that they had either "complete" (39\% of affiliated organisations) or "considerable" (48\%) authority on employment contracting policy and practice.

\section{Characteristics of the firms}

The industry profile of the sample of respondents, using an expanded version of the Standard Industry Classification system is presented in Table One. At various points in the presentation, an abbreviated version of the system is used where required to allow statistical testing and to highlight industry sectors generally identified as critical to national economic recovery.

There were some respondents with large numbers of business locations. However, $47 \%$ had only one location and close to $80 \%$ had less than 5 locations. About $33 \%$ of the respondents had all or the largest concentration of their employees in the Auckland region; $40 \%$ had all or the largest number of their employees elsewhere in the North Island; $27 \%$ had all or the largest number of their employees in the South Island.

There were significant patterns of industrial classification by location with, for example, primary industry organisations more likely to be in the South Island and manufacturing firms more likely to be in the North Island.

There were some very large employers in the sample, with 15 respondents having over 500 employees covered by union-negotiated awards or agreements prior to the implementation of the Employment Contracts Act. However, a little over 50\% of the

1 It may be of interest and concern to other researchers to note that the New Zealand Department of Statistics refused to make available for purchase for this project a sample from the Department's Business Directory. The stated reasons for the refusal was that the Department of Labour was commissioning a similar survey, thereby rendering this project of insufficient national importance to qualify for access to a sample. Reconsiderations of the initial refusal was offered conditional on the survey questionnaire, amongst other material, being submitted to the Department of Statistics for evaluation. This offer was declined and the initial request reiterated, but no further response was forthcoming from the Department. 
organisations had 25 or less employees covered by union-negotiated documents in the preAct era, while less than $20 \%$ had more than 100 .

\section{TABLE ONE: THE SAMPLE BY INDUSTRY CATEGORY}

\begin{tabular}{|lccc|}
\hline & Number & & Percentage \\
Agricultural servicing & 14 & \\
Agriculture, forestry, fishing & 13 & $2.5 \%$ \\
Mining \& quarrying & 10 & $2.3 \%$ \\
Food \& beverage manufacturing & 15 & $1.8 \%$ \\
Textile manufacturing & 9 & $2.7 \%$ \\
Wood products manufacturing & 15 & $1.6 \%$ \\
Printing \& publishing & 48 & $2.7 \%$ \\
Chemical based manufacturing & 19 & $8.6 \%$ \\
Metals based manufacturing & 37 & $3.4 \%$ \\
Other manufacturing & 19 & $6.6 \%$ \\
Electricity, water \& gas supply & 7 & $3.4 \%$ \\
Building \& construction & 71 & $1.3 \%$ \\
Food retail \& wholesale & 24 & $12.7 \%$ \\
Non-food retail \& wholesale & 98 & $4.3 \%$ \\
Restaurants \& accommodation & 19 & $17.6 \%$ \\
Transport, storage \& communication & 86 & $3.4 \%$ \\
Financial \& business services & 29 & $15.4 \%$ \\
Social \& personal services & 24 & $5.2 \%$ \\
& & $4.3 \%$ \\
\hline
\end{tabular}

\section{Pressure to reduce production costs}

Many firms were feeling under considerable pressure to reduce production costs, with two-thirds of the respondents reporting either "a great deal" or "intense" pressure to do so, and one-half of all firms reporting that the pressure was increasing.

The sources of pressure to reduce production costs were overwhelmingly associated with conditions in domestic markets rather than with international competition on- or offshore. By way of illustration, 400 of the 557 respondents cited "increased domestic competition in (their) domestic markets" as a source of pressure on the firm, while 389 cited a "reduction in domestic demand in the markets (they) service". In contrast, only 39 cited a "reduction in international demand in the markets (they) service", 85 cited "increased competition from offshore in (their) domestic markets", and 56 cited "increased competition in international markets (they) service". 


\section{The significance of contract structures}

To suggest that the Employment Contracts Act has facilitated an era of widespread employee concessions in recessed economic circumstances in New Zealand risks only understating the facts. A significant portion of the postal questionnaire from which the data reported in this paper are drawn consisted of a series of stated "problems" that were seen by advocates of labour market reform, amongst others, both as products of the former industrial relations system and as detracting from productivity and performance in New Zealand firms. Each respondent was asked to indicate whether, in fact, the "problem" had been seen as a problem in his or her firm, and if so, which if any of the solutions accompanying the problem statement were proposed and/or adopted in the transition to new contracts.

As detailed elsewhere (McAndrew, forthcoming 1993), virtually all employers who had implemented new contracts identified with one or usually more of the problems cited and had proposed and adopted various solutions. By way of illustration, restrictions on shift and weekend work were the most commonly mentioned problems, and expanding or eliminating the definition of normal hours and abolishing or reducing penal rates were among the most often proposed and adopted solutions. Not all of the solutions offered to all of the problems posed would be viewed as employee concessions, but certainly many of them would and the following comments relate just to those.

The adoption rate of concessions proposed was very impressive indeed. If an employer proposed a concession, it was very likely to be adopted in the transition to new contracts. Nonetheless, employers negotiating collective contracts were significantly less likely to have adopted concessions proposed than employers negotiating individual contracts.

The gap was somewhat diminished by a hybrid model under which some employers compiled collective contracts by dealing individually with each employee to be covered by the contract, and to a lesser extent by employers who dealt directly with their workforces as a whole rather than with representatives of the workforce. In each of these models, employers were more likely than those who dealt with workforce representatives to have achieved the concessions sought. Even so, the "adoption rate" gap between individual contracts and collective contracts as a whole remained at a statistically highly significant level.

Consistent with these findings, employers who had put in place individual contracts but no collective contracts were significantly more likely than those with collective contracts to say that changes implemented under the Act had resulted in productivity improvements for their firms, and were also likely to quote a higher productivity gain. The hybrid model of "collective bargaining individually" again tightened the gaps somewhat, but the differences remained significant.

In short, dealing with employees individually resulted in a greater probability of employee concessions and a correspondingly greater probability of perceived productivity improvement than was the case if employees were dealt with collectively.

The Employment Contracts Act has, then, facilitated significant reductions in labour costs, as well as perceived productivity improvement in many firms, and these impacts clearly vary with employment contract structures, there being marked differences between individual and collective contracts in these respects. The point of this paper is to examine whether the pattern of labour cost reductions, and attendant perceived productivity 
improvements, corresponds to and accommodates employer needs, or is in fact dictated by factors less rationally based, specifically pre-Act unions strength.

\section{The structure of new arrangements}

As noted early in this paper, structurally, the point of the Employment Contracts Act was to replace the predominant pattern of national, occupational multi-employer awards with arrangements centred at the enterprise or sub-enterprise levels. To a very considerable extent, this has been accomplished in the first year or so under the Act, as the following major points profile of the 557 organisations in the survey begins to illustrate:

* 90 firms reported having some or all employees still covered by a current award, agreement or contract pre-dating the Act;

* 207 firms had some or all employees on individual contracts under the terms of expired awards, agreements or contracts;

* 234 firms had some or all employees on new or renewed individual contracts developed under the Act

* 229 firms had some or all employees on new or renewed collective contracts developed under the Act

* 53 additional firms were working towards a new collective contract for some or all employees

A simple addition of these numbers suggests that the pattern is not an entirely tidy one. Many respondents reported a mix of arrangements for different employees or groups of employees.

A total of 73 organisations reported having no employees on either new contracts or award terms. Many of these reported that they were in the process of developing new contracts, and had varied some award terms in the meanwhile. Others had had no employees under union-negotiated documents in the pre-Act period and had modified but not formalised pre-existing arrangements.

\section{Collective contracts: the external structure}

As has been established elsewhere (Harbridge \& Moulder, 1992; Department of Labour, 1992), on the external dimension, the structure of collective documents has effectively been reversed. Of the 557 organisations in the survey, 491 had one or more employees covered by union negotiated documents at the time the Employment Contracts Act was implemented. Table Two shows a structural comparison of the documents covering the largest number of employees in each of those organisations before the Act (early 1991) with the major new documents in those 229 firms with new collective contracts in place at the time of the survey. 


\section{TABLE TWO: PROFILE OF COLLECTIVE DOCUMENT STRUCTURES}

\begin{tabular}{|l|c|c|}
\hline \multirow{2}{*}{ Major collective document in the firm } & \multicolumn{2}{|c|}{ Percentage of firms } \\
\cline { 2 - 3 } & Early 1991 & Mid 1992 \\
\hline A national or near-national award & $80 \%$ & $10 \%$ \\
A regional or local award & $8 \%$ & $2 \%$ \\
A contract exclusive to the firm & $9 \%$ & $80 \%$ \\
A contract exclusive to the parent company & $3 \%$ & $8 \%$ \\
\hline
\end{tabular}

\section{Collective contracts: the internal structure}

Internally, collective contract structures have also changed quite dramatically. Overwhelmingly (186 of 229), respondents who deal with any collective contracts now deal with only one. An additional 30 organisations reported having 2 applicable collective contracts, 7 reported having 3 , and only the remaining handful reported having more than 3 collective contracts applicable to the respondent employing unit. Second and subsequent collective contracts were, on the external dimension, almost entirely enterprise based.

Some additional structural characteristics of the major (and, as noted, usually the only) collective contract in the organisation are of interest. In 124 of the 229 organisations, all classes of employees previously represented under union-negotiated documents had been brought together under the collective contract. In most of the rest, coverage extended only to "production" employees, with support personnel either excluded or, in a minority of cases, covered under a second or subsequent collective contract. Correspondingly, such supplementary collective contracts, where they existed, were more likely than the major contract to exclusively cover support staff of one type or another.

In 109 of the 229 organisations, the major or only collective contract covered 25 or fewer employees, with only 33 contracts covering more than 100 employees. As might be expected, the percentages of second and subsequent contracts that covered 25 or less employees were progressively higher.

About one-half of the major collective contracts (114 of 229), and of the second and subsequent contracts as well, included some supervisory or management employees in coverage.

In 133 of the 229 organisations, some (in 22 firms) or usually all (in 111 firms) employees covered by the major collective contract had second-tier individual contracts or letters of appointment as well, spelling out individual pay rates, work schedules or other conditions of employment. This was significantly less likely to be the case in second and subsequent collective contracts within an organisation.

Finally on the internal structural dimension, 42 of the 229 organisations had one or more employees in classifications generally covered by the major collective contract on individual contracts outside the scope of the collective. This was somewhat more likely to be the case for second and subsequent collective contracts. With a few exceptions, the 


\section{The Structure of Bargaining under the ECA 269}

numbers of employees so separated from their colleagues generally represented quite small percentages of the covered classes.

\section{Examining structural patterns}

To examine contract or bargaining structures in terms of the analysis presented earlier in the paper, or to identify alternative explanations, several elements of structure were tested against organisational, market, and pre-Act labour relations characteristics.

Respondent organisations were categorised on one principal and three secondary structural dimensions:

1) Contract status: organisations ( $n=557)$ were categorised as either:

a) having employees exclusively on pre-Act award (or other document) terms, whether current or expired $(n=114)$;

b) having at least some employees on new (or renewed) individual contracts developed under the Act, but no employees on new (or renewed) collective contracts ( $\mathrm{n}=141)$

c) having no employees on either new (or renewed) contracts or pre-Act award (or other document) terms ( $\mathrm{n}=73$ ); or

d) having at least some employees on new (or renewed) collective contracts developed under the Act $(n=229)$.

In pure form, the pluralist analysis presented at the outset of this paper would suggest collective contracts for employees strongly unionised at the time of the implementation of the Act, and individual contracts for the rest of the workforce. Categories a) and c) are more ambiguous, there being a variety of possible explanations for employees being in either status, and a variety of final destinations towards which they might be headed.

There are, of course, qualifiers to this projection as noted earlier. Walsh (1991:168169) suggests "workers who possess skills or expertise in shor supply, or whose experience or particular abilities make them essential to their organisation", as well as those in secure relationships in some small workplaces as employees who may voluntarily seek individual rather than collective contracts. And he also outlines some limited circumstances under which some employers might seek collective rather than individual arrangements. No doubt there are others as well.

2) Type of collective contract (or the contract covering the largest number of the organisations employees in cases where more than one new collective contract has been developed): organisations ( $\mathrm{n}=229$ ) were categorised as having either:

a) a collective contract exclusive to either the immediate or a parent organisation ( $\mathrm{n}=201)$; or

b) a multi-employer collective contract $(n=28)$

"Type of collective contract" is included here as only a secondary structural dimension for a couple of reasons. First, under the influence of the Act, multi-employer contracts are relatively rare and the numbers may be insufficient to establish any reliable 
patterns. Second, particularly under circumstances where collective contracts might seem inevitable, either employers or unions may prefer multi-employer documents for their own reasons.

A purely pluralist analysis would suggest that the strongest unions would seek multiemployer documents to remove labour costs as a factor in competition to the extent that this remains feasible in the current market and legislative environments.

On the other hand, previous research (McAndrew \& Hursthouse, 1990) has suggested that many small and medium-sized firms were happy with the remoteness and convenience of the pre-Act award system, and some may seek to retain those advantages. Or, as noted by Walsh (1991: 172), there are likely to be still circumstances where employers want wages and conditions taken out of competition, and where they seek to do this through multi-employer contracts. And, he suggests, there may be industry sectors, such as the dairy industry, where a small number of major employers see advantages in coordinating their labour relations activities through a strong central body.

3) Number of collective contracts: organisations $(n=229)$ were categorised as having either:

a) one collective contract $(n=186)$; or

b) two or more collective contracts $(n=43)$.

Again, while the number of collective contracts is of interest and may be instructive, this dimension is included as only a secondary structural dimension, again for essentially the same two reasons. First, the number of respondents with more than one collective contract is small. Second, multiple contracts may be at the instigation of either employers or employees. Walsh (1991: 170) suggests that employees may push for multiple contracts "where dissimilar groups are bound into the same document and believe their particular needs can best be furthered by a series of collective contracts".

On the other hand, there is a considerable body of literature that suggests that, most obviously in large firms, decentralising of collective bargaining and contracts to the level of the individual plant or cost centre, resulting in multiple contracts, is an important managerial strategy both for generating productivity through internal competition and for insulating major decisions from union influence (Kochan, McKersie \& Cappelli, 1984; McKersie, 1987; Kinnie, 1987).

4) Second tier individual contracts: organisations $(n=229)$ were categorised as having either:

a) no employees covered by collective contracts also on second tier individual contracts $(n=96)$; or

b) some or all employees covered by collective contracts also on second tier individual contracts $(\mathrm{n}=133)$.

Again, where this practice is found, there can be no absolute certainty who initiated it. Walsh (1991: 167), for example, suggests that employees may seek second tier individual contracts to "pursue particular issues either not covered in the collective contract, or dealt with unsatisfactorily", and would certainly be likely to do so in preference to having an individual contract alone.

A conventional pluralist analysis, on the other hand, would have employers initiating this practice to facilitate individual performance based compensation and perhaps conditions; to enhance flexibility through individual schedules and conditions; and tactically, to reduce the cohesion of the workforce in collective bargaining. Perhaps for all of these reasons, but 
particularly the last, unions could be expected to resist the practice, strong unions most successfully.

To test the projections drawn from pluralist analysis, and to search for explanations where the analysis offers either competing or no specific projections, these structural dimensions were examined in relation to a number of organisational variables and against several pre-Act labour relations variables.

\section{Organisational variables}

The structural dimensions were examined against the following organisational variables: (1) the size of the workforce, as measured by the total number of the respondent organisation's employees covered by union-negotiated documents in the pre-Act era; (2) the industrial classification or main business of the organisation; and (3) the sources and extent of felt pressure to reduce production costs.

A number of other organisational variables, including whether the organisation was affiliated with a larger organisation or was independent, the number of places of business, and the gender makeup of the workforce were also looked at, but found to be related to one or another of the three principal variables. Accordingly, these subsidiary characteristics are mentioned only occasionally for particular points of interest in the following discussion.

\section{Size of the workforce}

Patterns of contract status were apparent by workforce size, both in terms of the likelihood of having made any new formal contractual arrangements and in terms of the structure of those new arrangements. Specifically, respondents with workforces of 25 or less employees were much more likely than larger organisations to report that they had not yet put new contracts in place, either leaving employees on pre-Act award terms or varying those terms without formalising new contracts.

Employers with 25 or fewer employees who had introduced new contracts were less likely than larger employers to have collective contracts, and correspondingly more likely to have introduced individual contracts. Employers with workforces in the 26 to 50 employees range were also more likely than larger firms to have introduced new individual contracts.

Amongst those organisations with collective contracts, a somewhat higher percentage of firms with 25 or less employees were covered by multi-employer documents than was the case with larger firms.

There was a predictable pattern to the number of collective contracts in those organisations with any collective contracts. Smaller firms were even more likely than others to have just one.

Respondent firms with 50 or less employees showed a higher propensity than larger firms to supplement collective contracts with second tier individual contracts, and the practice dropped off noticeably with workforces of over 100 . 


\section{2}

Ian McAndrew

\section{Industrial classification}

There were industrial patterns to all four of the structural dimensions described above. Contract status by industry is illustrated in Table Three.

TABLE THREE: CONTRACT STRUCTURES BY INDUSTRY SECTOR ( $\mathrm{n}=557)$

\begin{tabular}{|c|c|c|c|c|c|c|}
\hline & $\begin{array}{c}\text { PRIMARY }^{1} \\
(n=37)\end{array}$ & $\begin{array}{l}\text { MANUFACT }^{2} \\
(\mathrm{n}=162)\end{array}$ & $\begin{array}{l}\text { BUILDING }^{3} \\
(\mathrm{n}=71)\end{array}$ & $\begin{array}{c}\text { RETAII }^{4} \\
(\mathrm{n}=141)\end{array}$ & $\begin{array}{l}\text { TRANSPORT } \\
(\mathrm{n}=86)\end{array}$ & $\begin{array}{c}\text { OTHER }^{6} \\
(n=60)\end{array}$ \\
\hline $\begin{array}{l}\text { New IECs }{ }^{7} \text {, No } \\
\text { CECs }^{8}\end{array}$ & $\begin{array}{c}7 \\
(19 \%)\end{array}$ & $\begin{array}{c}31 \\
(19 \%)\end{array}$ & $\begin{array}{c}21 \\
(30 \%)\end{array}$ & $\begin{array}{c}37 \\
(26 \%)\end{array}$ & $\begin{array}{c}27 \\
(31 \%)\end{array}$ & $\begin{array}{c}18 \\
(30 \%)\end{array}$ \\
\hline New CECs & $\begin{array}{c}9 \\
(24 \%)\end{array}$ & $\begin{array}{c}88 \\
(54 \%)\end{array}$ & $\begin{array}{c}17 \\
(24 \%)\end{array}$ & $\begin{array}{c}56 \\
(40 \%)\end{array}$ & $\begin{array}{c}37 \\
(43 \%)\end{array}$ & $\begin{array}{c}22 \\
(37 \%)\end{array}$ \\
\hline $\begin{array}{l}\text { Award Terms } \\
\text { Only }\end{array}$ & $\begin{array}{c}13 \\
(35 \%)\end{array}$ & $\begin{array}{c}25 \\
(15 \%)\end{array}$ & $\begin{array}{c}14 \\
(20 \%)\end{array}$ & $\begin{array}{c}31 \\
(22 \%)\end{array}$ & $\begin{array}{c}13 \\
(15 \%)\end{array}$ & $\begin{array}{c}18 \\
(30 \%)\end{array}$ \\
\hline $\begin{array}{l}\text { No Contracts or } \\
\text { Awards }\end{array}$ & $\begin{array}{c}8 \\
(22 \%)\end{array}$ & $\begin{array}{c}18 \\
(11 \%)\end{array}$ & $\begin{array}{c}19 \\
(27 \%)\end{array}$ & $\begin{array}{c}17 \\
(12 \%)\end{array}$ & $\stackrel{9}{(10 \%)}$ & $\begin{array}{c}2 \\
(3 \%)\end{array}$ \\
\hline
\end{tabular}

Notes: 1. Includes the agriculture, hunting, forestry or fishing and the mining and quarrying industrial classifications. 2. The manufacturing industrial classifications. 3. The building and construction classification. 4. The wholesale or retail trade, or restaurants or hotels classification. 5. The transport storage or communication classification. 6 . Includes the business or financial services, community, social or personal services, and the electricity, gas or water supply industrial classifications. Includes many public enterprises. 7. IEC = individual employment contracts. $8 . \mathrm{CEC}=$ collective employment contracts. 9. Includes pre-Act enterprise agreements and individual arrangements in firms which had no employees covered by union-negotiated documents.

It is apparent from the table that the primary and construction sectors have acted with least urgency in putting new contractual arrangements in place, with high percentages of firms in these two categories either retaining employees exclusively on the terms of previous awards or acknowledging no formal contractual arrangements at all. Employers in the manufacturing, retail and transport sectors, and in parts of the "other" category have been most proactive in implementing new contracts, and are also most likely to have developed new collective contracts.

Some interesting, more detailed data are available within the abbreviated list of industry categories in the table, particularly in relation to collective contracts. For example, in the printing and publishing industry, 33 of 48 respondents $(69 \%)$ reported having collective contracts. Within the broad manufacturing sector, textile manufacturers were more likely than others to have reported collective contracts.

Amongst those respondents with collective contracts, the type of collective contract in the organisation showed industrial patterns. Most noteworthy was an even greater propensity in manufacturing than in other sectors to have put in place a contract exclusive to the organisation. Fully $88 \%$ of responding manufacturers with collective arrangements had enterprise contracts.

The retail and transport sectors showed a somewhat higher propensity than others for group or parent company contracts, and the retail sector a higher propensity than others for multi-employer contracts. Close to $20 \%$ of respondents with collective arrangements in the retail sector were covered by national multi-employer contracts and $68 \%$ had enterprise 
documents. Within this sector, however, food retailers had only enterprise documents, with the non-food retail and restaurant and accommodation sub-sectors accounting for the group and multi-employer arrangements.

The heavy count of collective contracts in the printing and publishing sector noted above consisted almost exclusively of enterprise documents.

Though the patterns were less vivid, industrial classification was also related to the number of collective contracts in those organisations with any collective contracts. In terms of the broad categories, the primary, manufacturing and building and construction sectors were even more likely than others to have just the one document.

Finally, there was a clear industrial configuration to the use of second tier individual contracts to supplement collective contracts, with this practice markedly most prevalent in non-food retail and in printing and publishing, and least prevalent in the primary and transport sectors. The application of second tier individual contracts to only some employees covered by a collective contract, rather than to all or none, was particularly popular only in non-food retailing.

\section{Production cost pressures}

There is a good deal of literature suggesting that product market structures and pressures substantially influence managerial industrial relations policies, including on the question of contract structure. In a vague way, publicists for the Employment Contracts Act embraced this view. There is also a countervailing body of literature that suggests that management in fact retains considerable room to make strategic industrial relations decisions, almost regardless of market pressures, perhaps subject to other limiting factors (see generally: Deaton \& Beaumont, 1980; Marchington, 1990).

Analysed in isolation from other variables, no discernable patterns were found between either the level or source of felt pressures to reduce production costs and any of the structural variables. To illustrate the point, Table Four presents the apparently erratic distribution of contract structures by felt pressure.

\section{Industrial Relations Characteristics}

In addition to the organisational characteristics dealt with above, the data were examined for any relationships between the several dimensions of contract structure and a number of industrial relations characteristics of the respondent organisations in the period leading up to the implementation of the Employment Contracts Act in May, 1991.

The industrial relations variables tested were (1) the nature of the union-negotiated document (and whether there was one) covering the largest number of the organisation's employees in the pre-Act period; (2) the pre-Act percentage of union membership among employees covered by that document, as estimated by the respondent; and (3) whether the respondent perceived "outside union interference" to have been a problem for the organisation in the period before the Act. 
TABLE FOUR: CONTRACT STRUCTURE BY PRODUCTION COST PRESSURES (n=557)

\begin{tabular}{|l|c|c|c|c|}
\cline { 2 - 5 } \multicolumn{1}{c|}{} & \multicolumn{4}{|c|}{ Level of pressure to reduce production costs } \\
\cline { 2 - 5 } \multicolumn{1}{c|}{} & $\begin{array}{c}\text { Little or none } \\
(\mathrm{n}=14)\end{array}$ & $\begin{array}{c}\text { Some } \\
(\mathrm{n}=181)\end{array}$ & $\begin{array}{c}\text { A great deal } \\
(\mathrm{n}=222)\end{array}$ & $\begin{array}{c}\text { Intense } \\
(\mathrm{n}=140)\end{array}$ \\
\hline New IECs, No CECs ${ }^{1}$ & $\begin{array}{c}1 \\
(7 \%)\end{array}$ & $\begin{array}{c}47 \\
(26 \%)\end{array}$ & $\begin{array}{c}54 \\
(24 \%)\end{array}$ & $\begin{array}{c}39 \\
(28 \%)\end{array}$ \\
New CECs & $\begin{array}{c}68 \\
(57 \%)\end{array}$ & $\begin{array}{c}102 \\
(38 \%)\end{array}$ & $\begin{array}{c}51 \\
(36 \%)\end{array}$ \\
No Contracts or Awards & 4 & 42 & 44 & 24 \\
$(29 \%)$ & $(23 \%)$ & $(20 \%)$ & $(17 \%)$ \\
1 & 24 & 22 & 26 \\
$(7 \%)$ & $(13 \%)$ & $(10 \%)$ & $(19 \%)$ \\
\hline
\end{tabular}

1. IEC = individual employment contract; CEC = collective employment contract. 2. Includes pre-Act enterprise agreements unchanged and individual arrangements in firms which had no employees covered by union negotiated documents.

\section{The major pre-Act document}

In the period leading up to the implementation of the Employment Contracts Act, all but 66 respondent organisations had employees subject to union-negotiated awards or agreements. As indicated previously, in most instances the document covering the largest number of the firm's employees was a national or near-national award. In smaller numbers of cases it was a regional or local award, an enterprise agreement or an agreement that extended to other employing units within a parent organisation, but no further.

The pattern of current contract status by pre-Act document structures is illustrated in Table Five.

Some of the figures in Table Five are not unexpected. Organisations which had no collective coverage before the Act are least likely to have collective coverage now. Those that had collective arrangements in place within the immediate or extended company before the Act are most likely to still have collective contracts, mostly renegotiated and possibly restructured.

Of interest, and perhaps less predictable, is the relatively high dissipation of local and regional awards into individual arrangements, by comparison with awards of broader coverage. 
The Structure of Bargaining under the ECA 275

\section{TABLE FIVE: CONTRACT STRUCTURE BY MAJOR PRE-ACT DOCUMENT ( $\mathbf{N}=557)$}

\begin{tabular}{|l|l|c|c|c|c|}
\cline { 2 - 6 } \multicolumn{1}{c|}{} & $\begin{array}{l}\text { National } \\
\text { Award } \\
(\mathrm{n}=392)\end{array}$ & $\begin{array}{l}\text { Regional } \\
\text { Award } \\
(\mathrm{n}=40)\end{array}$ & $\begin{array}{l}\text { Enterprise } \\
\text { Agreement } \\
(\mathrm{n}=44)\end{array}$ & $\begin{array}{l}\text { Parent Co. } \\
\text { Agreement } \\
(\mathrm{n}=15)\end{array}$ & $\begin{array}{l}\text { No } \\
\text { Collective } \\
\text { Document } \\
(\mathrm{n}=66)\end{array}$ \\
\hline New IECs, No CECs & $\begin{array}{c}88 \\
(22 \%)\end{array}$ & $\begin{array}{c}16 \\
(40 \%)\end{array}$ & $\begin{array}{c}7 \\
(16 \%)\end{array}$ & $\begin{array}{c}1 \\
(7 \%)\end{array}$ & $\begin{array}{c}29 \\
(44 \%)\end{array}$ \\
New CECs & $\begin{array}{c}172 \\
(44 \%)\end{array}$ & $\begin{array}{c}12 \\
(30 \%)\end{array}$ & $\begin{array}{c}22 \\
(50 \%)\end{array}$ & $\begin{array}{c}9 \\
(60 \%)\end{array}$ & $\begin{array}{c}14 \\
(21 \%)\end{array}$ \\
Award Terms Only & $\begin{array}{c}82 \\
(21 \%)\end{array}$ & $\begin{array}{c}11 \\
(28 \%)\end{array}$ & $\begin{array}{c}9 \\
(20 \%)\end{array}$ & $\begin{array}{c}8 \\
(27 \%)\end{array}$ \\
$(12 \%)$ \\
No Contracts or Awards & $\begin{array}{c}50 \\
(13 \%)\end{array}$ & $\begin{array}{c}1 \\
(2 \%)\end{array}$ & $\begin{array}{c}6 \\
(14 \%)\end{array}$ & $\begin{array}{c}1 \\
(7 \%)\end{array}$ \\
$(23 \%)$
\end{tabular}

1. IEC $=$ individual employment contract; $\mathrm{CEC}=$ collective employment contract. 2 . Includes pre-Act enterprise agreements unchanged and individual arrangements in firms which had no employees covered by union negotiated documents.

There were also some interesting patterns to the type of collective contract currently in place in those organisations with collectives, by comparison with pre-Act documents. Within the overall new pattern dominated by enterprise-based collectives, several points are worth noting. Predictably, firms with pre-Act in-house collective arrangements that have retained a collective contract approach still favour this structure. On the other hand, amongst those reporting new or renewed collectives, one-third of the organisations covered before the Act by parent company documents have now decentralised to enterprise contracts.

To the limited extent that they are covered by new collective arrangements at all, two groups are covered almost exclusively by enterprise documents: those without any preAct collective coverage and those covered pre-Act by local or regional awards.

In terms of the number of collective contracts in place in those organisations with any collectives, firms with pre-Act enterprise agreements were far more likely than others to be in the minority of organisations with more than one collective contract.

Finally on this variable, somewhat smaller percentages of organisations with either enterprise or parent company collective documents before the Act reported having second tier individual contracts, by comparison with all other categories.

\section{Pre-Act union membership}

With reference to the pre-Act document applicable to the largest number of their employees, respondents were asked what percentage of their employees covered by that document were union members prior to the implementation of the Act. As noted previously, 66 respondents had no employees covered by union-negotiated documents before the Act. 
Of those that did, 43 could not offer a union membership figure, while 448 were prepared to do so.

As illustrated in Table Six, there was a marked relationship between the reported percentage of union membership and current contract status.

\section{TABLE SIX: CONTRACT STRUCTURES BY PRE-ACT UNION MEMBERSHIP $(\mathrm{N}=\mathbf{4 4 8})$}

\begin{tabular}{|c|c|c|c|c|c|}
\hline & $\begin{array}{c}0 \% \\
(n=28)\end{array}$ & $\begin{array}{l}1-25 \% \\
(n=31)\end{array}$ & $\begin{array}{c}26-50 \% \\
(n=41)\end{array}$ & $\begin{array}{c}51-75 \% \\
(n=41)\end{array}$ & $\begin{array}{c}76-100 \% \\
(n=307)\end{array}$ \\
\hline New IECs, No CECs ${ }^{1}$ & $\begin{array}{c}8 \\
(29 \%)\end{array}$ & $\begin{array}{c}16 \\
(52 \%)\end{array}$ & $\begin{array}{c}8 \\
(20 \%)\end{array}$ & $\begin{array}{c}15 \\
(37 \%)\end{array}$ & $\begin{array}{c}58 \\
(19 \%)\end{array}$ \\
\hline New CECs & $\begin{array}{c}8 \\
(29 \%)\end{array}$ & $\begin{array}{c}9 \\
(29 \%)\end{array}$ & $\begin{array}{c}11 \\
(27 \%)\end{array}$ & $\begin{array}{c}15 \\
(37 \%)\end{array}$ & $\begin{array}{c}152 \\
(50 \%)\end{array}$ \\
\hline Award Terms Only ${ }^{2}$ & $\begin{array}{c}5 \\
(18 \%)\end{array}$ & $\begin{array}{c}3 \\
(10 \%)\end{array}$ & $\begin{array}{c}15 \\
(37 \%)\end{array}$ & $\begin{array}{c}9 \\
(22 \%)\end{array}$ & $\begin{array}{c}66 \\
(21 \%)\end{array}$ \\
\hline No Contracts or Awards & $\begin{array}{c}7 \\
(25 \%)\end{array}$ & $\begin{array}{c}3 \\
(10 \%)\end{array}$ & $\begin{array}{c}7 \\
(17 \%)\end{array}$ & $\begin{array}{c}2 \\
(5 \%)\end{array}$ & $\begin{array}{c}31 \\
(10 \%)\end{array}$ \\
\hline
\end{tabular}

1. IEC $=$ individual employment contract; $\mathrm{CEC}=$ collective employment contract. 2. Includes pre-Act enterprise agreements unchanged.

It would be an exaggeration to suggest that there are clear and consistent trend lines running through the data in Table Six. Nonetheless, it is apparent that workforces with high (76 - 100\%) union membership before the implementation of the Employment Contracts Act, and even those with merely majority $(51-75 \%)$ union membership, are more likely than those with minority union membership to now have collective contracts.

The percentage of pre-Act union membership also showed a relationship to the type of collective contract in place in those organisations with collective contracts. Most apparent within the new pattern of predominantly enterprise based collective contracts was the greater tendency for workforces with less than $75 \%$ union membership to be in the minority covered by multi-employer documents. To illustrate the point, workforces with high (76$100 \%$ ) union membership constituted about $75 \%$ of those with new or renewed collective contract coverage, but accounted for less than $50 \%$ of multi-employer document coverage reported.

Respondents reporting high $(76-100 \%)$ union membership were somewhat more likely than others to report having more than one collective contract. They were also markedly less likely than others to report having second tier individual contracts supplementing collective contracts. 
The Structure of Bargaining under the ECA 277

\section{Outside union interference}

Respondents were asked whether "outside union interference in the relationship between management and staff" had been seen as a problem in the organisation prior to the implementation of the Employment Contracts Act. One-third of respondents said that it had been a problem; two-thirds said that it had not.

Those that had seen unions as a problem in the past were more likely than others to have implemented new contractual arrangements of one type or another, and were very much less likely to have employees in the limbo status of "neither new contract nor old award".

Those that had seen unions as a problem in the past were also much more likely than the others to have collective contracts now. Of those that had collective contracts, employers who had not been bothered by unions in the past were more likely to be among the minority of respondents that were parties to multi-employer contracts.

There was no apparent pattern to the number of collective contracts in those organisations with collective contracts by past perceived union interference. Nor was there a link between perceptions of union interference in the past and the likelihood of having second tier individual contracts.

\section{The secondary structural variables}

In the earlier analysis, less confident projections were drawn in relation to what were identified as secondary structural variables than was so in relation to new contract status. The evidence on each of the former can be briefly examined before looking in more depth at the latter.

\section{Type of collective contract}

The minority of firms linked to multi-employer documents can be relatively easily profiled. Multi-employer contracts exist in a number of industries, the building industry in the south of the South Island being one example. However, almost $75 \%$ of the surveyed firms which were party to multi-employer documents were in either the manufacturing or retail sectors. Most had small workforces, less than high levels of pre-Act union membership, and no pre-Act problems of union interference. And most were in one of several multi-employer documents negotiated by the Engineers Union.

These firms would appear to be those that are left of the large numbers of employers identified in earlier research (McAndrew \& Hursthouse, 1990, 1991) as quite happy with the remoteness and convenience of the pre-Act award system and prepared to compete on the basis of something other than labour rates. It should be acknowledged that today's multi-employer documents tend to have considerable enterprise flexibility. As such, they perform essentially the same non-intrusive role for these employers as did minimumrate awards in the time before the Employment Contracts Act. 


\section{Number of collective contracts}

The data leads to little more than speculation regarding the minority of firms with multiple collective contracts. However, the facts that they are likely to have sizeable workforces and to have had high union memberships, and that they were likely to have had inhouse collective agreements before the Act are suggestive. The profile, though sketchy, is not inconsistent with a small number of more sophisticated firms acting strategically in a manner suggested by the Kochan et. al. literature referenced earlier. While the Act may have facilitated their strategies, most had been moving forward before its implementation.

\section{$\underline{\text { Second tier individual contracts }}$}

The evidence on the incidence of second tier individual contracts is inconclusive. The practice is very widespread among firms with collective contracts, in some industries more than others. It is most prevalent among the smallest firms with lowest union membership and least prevalent among larger firms with high union membership, and particularly among those that were pursuing enterprise strategies before the implementation of the Act.

It may be tempting to claim support for the pluralist contention that strong unions won't stand for fragmentation of the workforce through the device of individual second tier contracts. On the other hand, to the extent that there is a pattern, it may reflect nothing more than a continuation of the long standing and previously documented practice in many small firms of paying above-award individual rates (McAndrew \& Hursthouse, 1991).

\section{Explaining contract status}

Relative to what has been termed here "contract status", the analysis presented early in the paper projected that the Employment Contracts Act, by withholding support for collective bargaining, would lead to collective contracts amongst workforces well organised in effective unions at the time of the implementation of the Act, but not often amongst other workforces.

By the implication that pre-existing union strength would be the determining factor, it was projected that the pattern of contract status under the Act would be essentially unrelated to the particular needs or circumstances of the parties that featured so strongly in the rhetoric surrounding the introduction of the Act. Pressure to reduce production costs is the variable most closely identified with employer needs.

To sort through the variables, most of which showed patterns apparently associated with contract status, each of the contract status categories were tested using logistic regression analysis, with stepwise entry of variables. Except as noted, probability values were at the .01 level or better for each of the significant relationships reported below.

The only variables found to have value in predicting that an organisation would have employees in the "limbo" status of neither prior award nor new contract coverage were, in order of importance, the size of the workforce and the perception of union interference as having been a problem for the organisation in the past. 
It might reasonably be suggested that the perception of union interference as a problem in the past appears to have been a motivating factor in employers proactively moving to implement new arrangements, particularly in larger firms. Interestingly, beyond that point, union interference had no explanatory value in terms of the structure of the new arrangements.

None of the variables had any value as a predictor of firms still having employees exclusively on the terms of pre-Act awards or agreements.

Two variables, percentage pre-Act union membership and workforce size, in that order, were predictive of an organisation having new individual contracts but no collective contracts. The same two variables, in reverse order of impact, were predictive of new collective contracts. In short, individual contracts were most likely in small firms with low pre-Act union memberships, while collective contracts were most likely amongst larger workforces with high pre-Act union memberships.

Of the variables tested, the nature of the major pre-Act document proved insignificant. More interestingly, neither industry classification nor pressure to reduce production costs, as whole variables, had predictive value relative to contract status. A breakdown of the industry variable revealed links between the building and construction industry and the "neither old award nor new contract" status, and between the primary sector and the expired award status, though probability values were comparatively weak in both cases. Industry classification had no other predictive value. And neither the source nor the intensity of felt pressures to reduce production costs had any explanatory value in relation to contract status or structures.

\section{Conclusions}

The conclusions to this paper should be read quite narrowly. It is accepted, for example, that some restructuring and decentralisation of the labour relations system away from national occupational awards was necessary. At a substantive level, it is accepted, too, that some widespread work and compensation practices are probably as inappropriate to modern New Zealand as they were appropriate when initially agreed to decades ago.

The central thesis of the analysis presented early in this paper was that the Employment Contracts Act would be ineffective in tailoring labour relations arrangements, and hence employment contracting and its outcomes, to the needs and circumstances of particular workplaces. To a considerable extent, it was suggested, the Act would be shown to have simply tailored labour relations arrangements in accord with pre-existing union strengths and weaknesses, regardless of the productivity needs of the enterprise.

The data lend substantial support to this thesis. As previously noted, the levels of concession taking, of labour cost reduction and of perceived productivity improvement are directly tied to new contract structures, and particularly to the individual versus collective contract dimension. Crudely put, more concessions have been extracted from workforces that have been moved onto individual contracts than from those that have retained collective contract coverage. This will not, of course, be universally so. But it held true as a general rule across organisations in this sample, and at a statistically highly significant level.

Yet, of the several organisational variables tested, only workforce size is linked to contract status, a term used here to embrace both proactivity in implementing new contractual arrangements as well as the structure of new contracts and of the bargaining that 
produced them. Contract status, contract structures, the level of employee concessions, and perceived productivity improvements are unrelated, and presumably unresponsive to the needs of employing organisations to reduce production costs; and, somewhat surprisingly, but consistently, they are essentially unrelated even to industry classification.

To illustrate the point, the figures in Table Four, for example, reveal that firms subject to some, little or no production cost pressures, on the one hand, and those with a great deal or intense pressure to reduce production costs, on the other, each adopted individual contracts in about $25 \%$ of cases and each adopted collective contracts in about $40 \%$ of cases. In sum, the data suggest that the patterns of adjustment under the Employment Contracts Act bear no relationship to either the markets in which employing organisations operate or the positions of organisations in their markets.

In the short term, this unhelpful pattern is effectively hidden because, under the influence of the ongoing economic malaise, the survey results indicate that virtually all employers who have implemented new contracts have been able to use the Act to revise terms and conditions of employment to some degree in a direction more to their liking.

There is considerable support in the data for the initial projection that, under the Employment Contracts Act, employees well organised in effective unions at the time of the implementation of the Act would secure for themselves collective contracts, and the greater resistance to concessions that collective bargaining brings, while employees not so well organised before the Act took effect would most likely be found faring less well on individual arrangements.

Two union variables have featured in the analysis: union membership and the perception of unions as a problem in the past. It was envisioned that the union interference variable might reflect the local visibility and activity level of the union and, as such, be a useful measure of some necessary ingredients for union effectiveness in the new environment. It is not entirely clear what, in fact, this variable measures. Its apparent role in motivating employers to formalise new arrangements of one type or another could be consistent with either union interference as a proxy for union effectiveness or union interference as simply a nuisance to be avoided by early attention to new contracts. As noted, the union interference variable did not feature further as a factor in the structure of new contracts.

On the other hand, union membership strength was, along with workforce size, an important predictor of whether an organisation has collective or individual contracts. As predicted, workforces with high union membership before the Employment Contracts Act took effect are significantly more likely than others to now have collective contracts, and accordingly to have sacrificed least by way of concessions to employers, regardless of either the employer's need for concessions or the workforce's capacity to absorb them.

To conclude, the Employment Contracts Act licensed wholesale concession taking from employees, prompted by the legitimate and widely recognised need to improve productivity in many New Zealand workplaces through a restructuring of labour relations, but unrestrained by any recognition of the legitimate rights of employees to be represented effectively in the process. With a bottomless labour market and few statutory minima, employer responsibility and self-restraint and the industrial strength of particularly larger workforces have been the only moderating influences.

Statistical analysis indicates relationships and trends, not absolutes. Clearly, significant numbers of employers, even absent industrially strong workforces, have fashioned new contractual arrangements and new terms of employment in tailored reaction to their particular circumstances, with or without employee input, but with an appreciation of 
employee needs. This sagacity of many New Zealand managements should not be understated or undervalued.

The evidence of this paper is, however, that these factors have been insufficient to prevent an overall pattern of concession taking that bears virtually no relationship to the differing market circumstances of New Zealand businesses. It is difficult to imagine that either the non-rational pattern of concession taking or the demonstration effect of industrial strength as the best defence will escape the attention of the greater New Zealand workforce.

\section{References}

Boxall, P. (1991), New Zealand's Employment Contracts Act 1991: An Analysis of Background, Provisions and Implications, Australian Bulletin of Labour, 17(4): 284-309.

Boxall, P. (1990), Towards the Wagner Framework: Change in New Zealand Industrial Relations, The Journal of Industrial Relations, 32(4): 523-543.

Department of Labour (1992), Contract: The Report on Current Industrial Relations in New Zealand, 1-4.

Deaton, D.R. \& P.B. Beaumont (1980), The Determinants of Bargaining Structure: Some Large Scale Survey Evidence for Britain, British Journal of Industrial Relations, 18(2): 202216.

Geare, A.J. (1988), The System of Industrial Relations in New Zealand, Wellington, Butterworths.

Harbridge, R. \& J. Moulder (1992), Collective Bargaining and the Employment Contracts Act 1991: One Year On. Paper presented to Victoria University of Wellington Industrial Relations Seminar, May 15, 1992.

Harbridge, R. \& S. McCaw (1991), The Employment Contracts Act 1991: New Bargaining Arrangements in New Zealand, Asia Pacific Human Resource Management, Spring: 5-26.

Kinnie, N. (1987), Bargaining Within the Enterprise: Centralized or Decentralized?, Journal of Management Studies, 24(5): 463-477.

Kochan, T.A., R.B. McKersie \& P. Cappelli (1984), Strategic Choice and Industrial Relations Theory, Industrial Relations, 23(1): 16-39.

Marchington, M. (1990), Analysing the Links Between Product Markets and the Management of Employee Relations, Journal of Management Studies, 27(2): 111-132.

McAndrew, I. (forthcoming 1993), The Process of Developing Employment Contracts: The Management Experience. In: R. Harbridge (ed.) Employment Contracts: Early New Zealand Experiences, Wellington, Victoria University Press. 


\section{Ian McAndrew}

McAndrew, I. \& P. Hursthouse (1990), Southern Employers on Enterprise Bargaining, New Zealand Journal of Industrial Relations, 15(2): 117-128.

McAndrew, I. \& P. Hursthouse (1991), Reforming Labour Relations: What Southern Employers Say, New Zealand Journal of Industrial Relations, 16(1): 1-11.

McKersie, R.B. (1987), The Transformation of American Industrial Relations: The Abridged Story, Journal of Management Studies, 24(5): 433-440.

Walsh, P. (1991), Bargaining Options Under the Employment Contracts Act, New Zealand Journal of Industrial Relations, 16(2): 167-174. 